\title{
Researches on the Influence of the Sowing Period of Simple Hybrids on Seed Production for the Turda 200 Maize Hybrid
}

\author{
Alexandru B. GHEȚE ${ }^{1}$, Ana COPÂNDEAN² ${ }^{2}$, Voichița V. HAȘ², Cornel CHEȚAN² ${ }^{2}$ Marcel DUDA ${ }^{1}$, Roxana E \\ CALUGAR $^{1}$, Andrei VARGA ${ }^{1}$ \\ ${ }^{1}$ University of Agriculture Sciences and Veterinary Medicine, Cluj - Napoca, Calea Manastur, no. 3-5, \\ 400372 Cluj-Napoca, Romania \\ ${ }^{2}$ Agricultural Research and Development Station Turda, Agriculturii St., no.27, Turda, Romania \\ *corresponding author, e-mail: ghetealexandrubogdan@gmail.com
}

Bulletin USAMV series Agriculture 74(2)/2017

Print ISSN 1843-5246; Electronic ISSN 1843-5386

DOI 10.15835/buasvmcn-agr: 0006

\section{INTRODUCTION}

The production of certified seed for maize double hybrids is based on the crossing of two simple maize hybrids, one of which is used as a seed producer (maternal form, AxB) and another as pollinator (paternal form, $\mathrm{CxD}$ ). The production of the seed in the case of double hybrids presents some advantages because the production obtained in the hybridization lot is high, the cost of lower seed production and includes a minimum risk (Penčić and Hadžistević, 1982). Seed quality indices are generally better than by simple hybrids, especially when adverse conditions occur during production (Sarca, 2004).

In the production of corn seed, the relationship between the maternal and paternal form is determined by the amount of the pollen of the paternal form, the habitus of the two partners, the sowing mode of the two cross-breeders (concomitant or offset). The possibilities of seed ratio provided by the existing seeds on the agricultural holding and the mode of harvesting each parental form (Haș, 2006).

The main features of seed production at the Turda 200 hybrid recommended by ARDS Turda in 2001 year were:

- The reaction to androsterility of the maternform: androsterile;

- The mother/ father sowing ratio recommended by SCA Turda (2001) was 6: 2 or 12: 4 , the recommended density was 50.000-60.000 plants per hectare for the parental form and 60.000-70.000 plants per hectare for the father form;

- The sowing mode of the two parental forms was concomitant;

- Special works: control of androsterility;

- The amount of useful heats needed for maturity of the maternal form of $1.090^{\circ} \mathrm{C}$

Haș et al. (1982) have found that under certain warmer summer conditions there may be a gap in favor of blooming father form up to -8 days. In this situation, it is appropriate to make the offset sowing of the two parental forms, in the first epoch, to resemble the matern form, and the sowing of the pollination form to be done at the rising of the maternal form.

Our study aims to verifying the sowing ratio between simple parental hybrids at HD Turda 200, and indentifying the influence of concomitant/ offset sowing of simple parental hybrids on seed production $\mathrm{F} 1$ and its characters.

\section{MATERIALS AND METHODS}

The material used was represented by the maize simple hybrids, the parental forms of the Turda 200 double hybrid.

For the production of seed for the Turda 200 double hybrid, the following technological features were considered: 
- For preparing the land were been applied classical technology for maize, autumn plowing and combiner preparing before sowing.

- Sowing was performed:

- 25.04.2015, in the case of concomitant sowing (matern form + paternal form)

- 25.04.2015, in the case of offset sowing (parent form +2 paternal lines and 03.05.2015 the other two paternal rows) at 8 days distance other 2 pollinating rows.

- Fertilization $200 \mathrm{Kg} / \mathrm{ha} \mathrm{N}: \mathrm{P}: \mathrm{K}, 18: 46: 0$ + vegetation $120 \mathrm{~kg} / \mathrm{ha}$ Nitrocalcar

- Pre-emergence herbicide 1.5l / ha Tender + 0,4l / ha Merlin Flex, on 4 leaf stage 0.8l/ha Esteron

Within the seed production lot for the Tuda 200 hybrid, two experimental plots were delineated, one of which the parental forms were sowed concomitant, and the other parcel that the parental forms were sown offset. For each plot, three sampling points were selected, thus constituting the three rehearsals of the experience. The harvest points were established diagonally on each plot so that the results were as representative as possible for the whole lot. Samples were harvested on each row on an area of 10 square meters, the row 1 being $70 \mathrm{~cm}$ from the paternal form, and the row 4 being $280 \mathrm{~cm}$ from the paternal shape.

In order to accomplish this study, the results obtained were collected from the maize seed lot established in 2015, being made in the mode of a bifactorial experience. The first factor was the sowing mode of simple parental hybrids having two graduations, sowing concomitent of the parental forms and offset sowing the pollinating form; sown in two eras: two rows being sowed on the same date as the matern form and two more rows being sowed at 8 days apart. The second factor studied was the degree of distance of the maternal hybrid from the pollination form, this factor having four graduations, represented by the four matern rows.

In order to achieve the proposed objectives at full grain maturity, a series of production determinations were made for the following characters:

- Seed quantity / ha

- Grains yield on ear

- Grains humidity at harvest

- Thousand kernels weight (TKW).

\section{RESULTS AND DISCUSSIONS}

The 2015 year in which this study was carried out, was characterized by the thermal values presented in Tab. 1 . The average monthly temperatures recorded during the maize vegetation period were higher than the average of multiannual temperature values, the only month with lower temperatures being April, which was cooler by $0.2^{\circ} \mathrm{C}$ compared to the average of April for the last 57 years.

The amount of rainfall recorded in the year 2015 in the maize growing period was 556.3 $\mathrm{mm}$, compared to the average of the last 57 years of $401.8 \mathrm{~mm}$. Although the sum of rainfall in the maize growing season for 2015 was above the multiannual average over the same period, precipitation distribution was not favorable for maize culture. Due to the rainfall shortage during the pollination period of the maternal form, there were some decreases in the grain production values for the Turda 200 hybrid (Tab. 1), especially in the offset seeding mode.

According to the study conducted in 2015 year, it was found that the maize grains yield on the Turda 200 hybrids was not influenced by the sowing mode, the differences observed between the two studied sowing modes being statistically uninsured (Tab. 2).

However, the results obtained with regard on the TKW of the obtained seeds indicated that the offset sowing of the paternal form induces a decrease in the values of this character, being probably influenced by the July drought (Tab. 1), the pollination of the kernels being incomplete, this contributed thus at a lower yield of seeds on the cobs (Tab. 2).

The moisture content of the harvesting seeds for the Turda 200 hybrid recorded close values for the two sowing modes studied, the differences in the humidity values of the two sowing modes were not statistically significant, although for offset sowing mode the grain humidity was higher by about $2 \%$ compared to the concomitant sowing. After analyzing the results of the production, it was observed that the sown sowed production was lower, contrary to the literature, but the difference was $541 \mathrm{~kg} / \mathrm{ha}$ (Tab. 3), a relatively low and statistically uninsured value (according to Ioan Haş's remark on the decrease of the production of the maternal form, for the sowing offset, in the conditions of drought in the blooming period - 
Tab. 1. The thermal and pluviometric regime recorded at the meteorological station at ARDS Turda, in 2015

\begin{tabular}{cccccccc}
\hline & April & May & June & July & August & September & October \\
\hline & & \multicolumn{7}{c}{ Temperature $\left({ }^{\circ} \mathrm{C}\right)$} \\
\hline Monthly average & 9.6 & 15.8 & 19.4 & 22.3 & 21.9 & 17.3 & 9.7 \\
\hline 57 years average & 9.8 & 14.7 & 17.7 & 19.6 & 19.2 & 14.9 & 9.6 \\
\hline 2015 deviation & -0.2 & +1.1 & +1.7 & +2.7 & +2.7 & +2.4 & +0.1 \\
\hline & & & & Precipitations $(\mathrm{mm})$ & & \\
\hline Monthly average & 32.2 & 66.0 & 115.7 & 52.2 & 72.2 & 172.6 & 45.4 \\
\hline 57 years average & 44.7 & 67.7 & 84.5 & 76.7 & 55.9 & 40.3 & 32.0 \\
\hline 2015 deviation & -12.5 & -1.7 & +31.2 & $-\mathbf{2 4 . 5}$ & +16.3 & +132.3 & +13.4 \\
\hline
\end{tabular}

*database source:Meteorological Station Turda (longitude: $23^{\circ} 47^{\prime}$; latitude $46^{\circ} 35^{\prime}$; altitude $427 \mathrm{~m}$ )

Tab. 2.Influence of sowing mode on grains yield percent per cobs and TKW values, Turda 2015

\begin{tabular}{ccccc}
\hline Sowing mode & $\begin{array}{c}\text { Yield } \\
(\%)\end{array}$ & $\mathbf{\pm}$ Control & $\begin{array}{c}\text { TKW } \\
(\mathrm{g})\end{array}$ & \pm Control \\
\hline Concomitant & 79.56 & control & 231.45 & control \\
\hline Offset & 77.91 & -1.65 & 207.86 & $-23.59^{0}$ \\
\hline LSD $(\mathrm{p}<5 \%)$ & & 1.99 & & 16.84 \\
LSD $(\mathrm{p}<1 \%)$ & & 4.59 & & 38.88 \\
LSD $(\mathrm{p}<0.1 \%)$ & & 14.62 & & 123.72 \\
\hline
\end{tabular}

ANOVA programme

Tab. 3. Influence of sowing mode on grains humidity and grains production per hectare,Turda 2015

\begin{tabular}{ccccc}
\hline Sowing mode & $\begin{array}{c}\text { Grain humidity } \\
(\%)\end{array}$ & \pm Control & $\begin{array}{c}\text { Grain production } \\
(\mathrm{kg} / \mathrm{ha})\end{array}$ & \pm Control \\
\hline Concomitant & 20.68 & control & 5779 & control \\
\hline Offset & 22.73 & 2.05 & 5238 & -541 \\
\hline LSD $(\mathrm{p}<5 \%)$ & & 2.24 & & 1405 \\
LSD $(\mathrm{p}<1 \%)$ & & 5.16 & & 3246 \\
LSD $(\mathrm{p}<0.1 \%)$ & & 16.43 & & 10329 \\
\hline
\end{tabular}

ANOVA programme

the appearance of the stigmata, as it happened in 2015).

The interaction between the sowing mode and the distance to the paternal lines shows some differences in the grains yield percent on the cobs.
At the concomitant sowing of the two simple hybrids, parental forms, the grains yield on the cobs drops directly proportional to the removal from the pollinating form (Tab. 4). In the case of the offset sowing mode of the parental forms, for 
the studied hybrid, better pollination was ensured in the case of the rows which were more distant from the paternal form, respectively the rows 3 and 4. Under the envirnonmental conditions of ARDS Turda in 2015, the interaction between sowing mode and distance to paternal form did not show significant differences after the variance analysis.The fact that there were no significant differences between the closest one to the father and the farthest, on the grains yield percent on the cobs, has shown that the ratio of sowing between the two parental forms is optimal.

Tab. 4. Influence of the interaction between the distance from the paternal form and the sowing mode of the parental forms on the grains yield on the cobs and TKW, Turda 2015

\begin{tabular}{cccccc}
\hline \multirow{2}{*}{ Sowing mode } & Distance & $\begin{array}{c}\text { Yield } \\
(\%)\end{array}$ & \pm Control & \multicolumn{1}{c}{$\begin{array}{c}\text { TKW } \\
(\mathrm{g})\end{array}$} & \pm Control \\
\hline \multirow{3}{*}{ Concomitant } & Row 1 & 79.97 & control & 222.86 & control \\
\cline { 2 - 6 } & Row 2 & 80.20 & 0.23 & 218.64 & -4.53 \\
\cline { 2 - 6 } & Row 3 & 79.17 & -0.80 & 246.03 & $30.10^{* *}$ \\
\cline { 2 - 6 } & Row 4 & 78.90 & -1.07 & 238.25 & 19.57 \\
\hline \multirow{2}{*}{ Offset } & Row 1 & 77.47 & control & 211.10 & control \\
\cline { 2 - 6 } & Row 2 & 78.70 & 1.23 & 207.18 & -4.63 \\
\cline { 2 - 6 } & Row 3 & 77.47 & 0.00 & 203.15 & -7.17 \\
\hline LSD $(\mathrm{p}<5 \%)$ & Row 4 & 78.00 & 0.53 & 210.01 & -1.77 \\
LSD $(\mathrm{p}<1 \%)$ & & & 1.60 & & 18.45 \\
LSD $(\mathrm{p}<0.1 \%)$ & & & 2.25 & & 36.59 \\
\end{tabular}

ANOVA programme

Tab. 5. Influence of the interaction between the distance from the paternal form and the sowing mode of the parental forms on the grain humidity and the grain production

\begin{tabular}{|c|c|c|c|c|c|}
\hline Sowing mode & Distance & $\begin{array}{l}\text { Grain humidity } \\
\text { (\%) }\end{array}$ & \pm Control & $\begin{array}{c}\text { Grain } \\
\text { production } \\
(\mathrm{kg} / \mathrm{ha})\end{array}$ & \pm Control \\
\hline \multirow{4}{*}{ Concomitant } & Row 1 & 20.07 & control & 5706 & control \\
\hline & Row 2 & 19.87 & -0.20 & 6196 & 489 \\
\hline & Row 3 & 21.73 & $1.67^{*}$ & 5397 & -309 \\
\hline & Row 4 & 21.03 & 0.97 & 5820 & 113 \\
\hline \multirow{4}{*}{ Offset } & Row 1 & 22.70 & control & 5783 & control \\
\hline & Row 2 & 22.47 & -0.23 & 5042 & -741 \\
\hline & Row 3 & 23.23 & 0.53 & 5353 & -430 \\
\hline & Row 4 & 22.50 & -0.20 & 4777 & -1006 \\
\hline LSD ( $\mathrm{p}<5 \%)$ & & & 1.34 & & 1279 \\
\hline LSD (p<1\%) & & & 1.89 & & 1795 \\
\hline $\operatorname{LSD}(p<0.1 \%)$ & & & 2.66 & & 2534 \\
\hline
\end{tabular}

ANOVA programme 
The results obtained with regard to seed TKW showed a distinctly significant difference to concomitant sowing mode for row 3 of the maternal form, the other differences being statistically uninsured. Due to the fact that the results obtained on this character are not been repeated (being obtained in only one experimental year) it is necessary to take into account the possible major influence of the climatic conditions, it is known that the process of grain filling is conditioned by the presence of precipitations recorded during and after pollination (Tab. 4).

For the double hybrid studied, it was found that generally the sowing mode did not signifi-

Tab. 6.Influence of the interaction between the sowing mode and the distance from the paternal form on the grain yield on the cobs, Turda 2015

\begin{tabular}{lccccc}
\hline Sowing mode & Distance & $\begin{array}{c}\text { Yield } \\
(\%)\end{array}$ & \pm Control & $\begin{array}{c}\text { TKW } \\
(\mathrm{g})\end{array}$ & \pm Control \\
\hline Concomitant & Row 1 & 79.97 & control & 222.86 & control \\
\hline Offset & Row 1 & 77.47 & -2.50 & 211.10 & -11.76 \\
\hline Concomitant & Row 2 & 80.20 & control & 218.64 & control \\
\hline Offset & Row 2 & 78.70 & -1.50 & 207.18 & -11.47 \\
\hline Concomitant & Row 3 & 79.17 & control & 246.03 & control \\
\hline Offset & Row 3 & 77.47 & -1.70 & 203.15 & $-42.88^{00}$ \\
\hline Concomitant & Row 4 & 78.90 & control & 238.25 & control \\
\hline Offset & Row 4 & 78.00 & -0.90 & 210.01 & $-28.24{ }^{0}$ \\
\hline LSD $(\mathrm{p}<5 \%)$ & & & 2.29 & & 22.02 \\
LSD $(\mathrm{p}<1 \%)$ & & 4.28 & & 38.10
\end{tabular}

ANOVA programme

Tab. 7. Influence of the interaction between the sowing mode and the distance from the paternal form on the grains humidity and the grains production Turda 2015

\begin{tabular}{cccccc}
\hline Sowing mode & Distance & $\begin{array}{c}\text { Grain } \\
\text { humidity } \\
(\%)\end{array}$ & \pm Control & $\begin{array}{c}\text { Grain } \\
\text { production }(\mathrm{kg} / \\
\text { ha) }\end{array}$ & \pm Control \\
\hline Concomitant & Row 1 & 20.07 & control & 5706 & control \\
\hline Offset & Row 1 & 22.70 & $2.63^{*}$ & 5782 & 76.65 \\
\hline Concomitant & Row 2 & 19.87 & control & 6195 & control \\
\hline Offset & Row 2 & 22.47 & $2.60^{*}$ & 5041 & -1154.14 \\
\hline Concomitant & Row 3 & 21.73 & control & 5397 & control \\
\hline Offset & Row 3 & 23.23 & 1.50 & 5353 & -43.88 \\
\hline Concomitant & Row 4 & 21.03 & control & 5819 & control \\
\hline Offset & Row 4 & 22.50 & 1.47 & 4776 & -1042.69 \\
\hline LSD $(\mathrm{p}<5 \%)$ & & & 2.39 & 1691.87 \\
LSD $(\mathrm{p}<1 \%)$ & & & 13.11 & 3063.72
\end{tabular}

ANOVA programme 
cantly affected the grain humidity regardless of the distance from the paternal form, with the exception of row 3 of the maternal form (Tab. 5), in which case were founded significant differences for the character studied.

Regarding the production of seeds/ha, it was found that the differences between its values under the interaction between the two factors studied did not have statistical significance. However, in the case of the offset sowing mode, it was noticeable that the production decreased with increasing distance from the paternal form.

Comparing the rows equally spaced from the paternal form to the two sowing modes, it was observed that the grain yield was not signifient influenced by the sowing mode (Tab. 6). TKW values for offset sowing mode decreased to row 3 and 4 showing distinctly significant negative differences, respectively significant negative compared to the same rows in case of concomitant sowing mode (Tab. 6).

The rows equally spaced from the pollinating form recorded higher moisture values for the offset sowing mode of parental forms, this difference being probably the result of a longer pollination period, so some seeds mature later. Between the ranks equally spaced from the paternal form for the two sowing modes were not statistically significant differenced.

\section{CONCLUSIONS}

The concomitant or offset sowing mode of the parental forms of the Turda 200 hybrid showed insignificant differences for the production values, grains yield or humidity. Significant negative differences were recorded only in the case of TKW, in the offset sowing mode.

Grains production was not significantly influenced by the distance to the pollinating form, even if decreases of its values were proportional to the increase in distance from pollinating rows.

The interaction between the distance to the pollinating form and the sowing mode did not show statistical differences in the production of the seeds maize.

As a result of the interaction between the sowing mode and the distance to the pollinating rows, the production did not show significant differences. In this case, some significant positive differences were observed only regarding the humidity and TKW values, the offset sowing mode was showing higher humidity values and lower TKW values.

\section{REFERENCES}

1. Haș I, Căbulea I, Haș V, Nagy C (1982). Research on some technological features of seed production of inbred lines and simple hybrids parental of maize. - contributions of scientific research to the development of agriculture, Bucharest.

2. Haș I 92006). Production of seeds in agricultural plants AcademicPres Publishing House, Cluj-Napoca.

3. Sarca V (2004). Monography of maize. Romanian Academy Publishing House, Bucharest.

4. Haș I, Căbulea I, Grecu C, Haș V, Copândean A (1994). The technological particularities of the seed production of the new maize hybrids created in S.C.A. Turda. Contributions of Scientific Research to Agricultural Development, V:153159.

5. *** (2001). SCA Turda Ed. The main characteristics of seed production at the hybrids created at SCA Turda, Hiperborea Turda Printing House 